\section{A New Synthesis of Model Compounds for the $\beta-5$ Structural Unit in Lignins}

\section{GÖSTA BRUNOW * and KNUT LUNDQUIST}

Department of Organic Chemistry, Chalmers University of Technology and University of Göteborg, S-412 96 Göteborg, Sweden

The $\beta-5$, or phenylcoumaran linkage is an abundant structural element in lignins. ${ }^{P}$ Until recently, the only practical synthetic route to this structure was the oxidative dimerization of $p$ propenylphenols such as isoeugenol ${ }^{2}$ and coniferyl alcohol. ${ }^{3}$ Apart from the fact that the desired dimers have to be separated from large amounts of other products formed in the reaction, this synthesis is unsuited for unsymmetrical phenylcoumarans and for oligomeric model compounds containing three or more phenylpropane units. A "rational" synthesis that avoids these problems has recently been reported. ${ }^{4}$ Here we describe an alternative and shorter synthetic route to the phenylcoumaran structure.

The synthesis is an extension of our recently published synthesis of $\beta-1$ model compounds (1,2-diarylpropane-1,3-diols) ${ }^{5,6}$ It starts with the preparation of chalcone 1 which is formed in good yield from easily available starting materials. Epoxidation under phase transfer conditions afforded epoxide 2 . Rearrangement of 2 with boron trifluoride diethyl etherate in refluxing diethyl ether and subsequent reduction of the product with sodium borohydride yielded a mixture which, after column chromatography, gave $38 \%$ of crystalline 1,2-diarylpropane-1,3-diol 3 . This is probably the erythro isomer in analogy with other 1,2-diarylpropane-1,3-diols prepared in a similar manner. ${ }^{6}$

Debenzylation with hydrogen over a palladium catalyst in dry dioxane gave a quantitative yield of 4. This compound is to our knowledge the first synthetic "open" structure corresponding to a phenylcoumaran. No spontaneous ring closure was observed with 4 either in dioxane solution or on evaporation of the solvent. Only after addition of a catalytic amount of hydrochloric acid to the dioxane solution did a cyclization to the phenylcoumaran 5 take place. When debenzylation of 3 was done using methanol as solvent,

* Permanent address: Department of Chemistry, University of Helsinki, Vuorikatu 20, SF-00100 Helsinki, Finland.

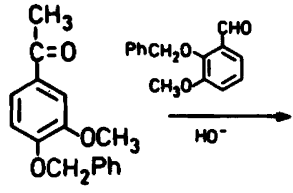<smiles>COc1ccc(C(=O)c2cccc(OCc3ccccc3)c2OCc2ccccc2)cc1OC</smiles><smiles></smiles>

2<smiles>CCOCCCCC(C)(C)[Mg]</smiles><smiles>COc1cccc(C(O)C(CO)c2cccc(OC)c2)c1</smiles><smiles>COc1ccc([C@@]2(CO)COc3c(OC)cccc32)cc1O</smiles>
$3 \mathrm{R}=-\mathrm{CH}_{2} \mathrm{Ph}$

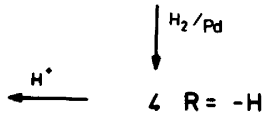

normal work-up (filtration of the catalyst and evaporation of the solvent) gave 5 directly.

The ${ }^{1} \mathrm{H}$ NMR spectrum of the diacetate of 5 was similar to that of dihydrodehydrodiconiferyl alcohol and dehydrodiisoeugenol ${ }^{7}$ indicating that the substituents at the coumaran ring are trans as shown in the Formula.

The unexpected stability of 4 supports the assumption ${ }^{8}$ that such units can exist as such in lignins. They have in fact been found in certain naturally occurring lignans. ${ }^{9}$

Experimental. ${ }^{1} \mathrm{H}$ NMR spectra were recorded on a Bruker WH 270 instrument with chloroform- $d$ as solvent. The high resolution mass spectrum was obtained with a VG Analytical ZAB instrument. Melting points were determined using a Mettler hot stage on a polarizing microscope.

1-(4-Benzyloxy-3-methoxyphenyl)-3-(2-benzyloxy-3-methoxyphenyl)-2-propen-1-one (1). The compound was prepared from the benzyl ethers of 1-(4-hydroxy-3-methoxyphenyl)ethanone and 2-hydroxy-3-methoxybenzaldehyde using the procedure described in Ref. 5 . The product was a yellow oil which crystallized slowly on standing. Recrystallized from ethanol, m.p. $91^{\circ} \mathrm{C}$, yield $83 \%$. ${ }^{1} \mathrm{H}$ NMR spectrum: $\delta 3.89\left(3 \mathrm{H}, \mathrm{s} ; \mathrm{OCH}_{3}\right)$, $3.92\left(3 \mathrm{H}, \mathrm{s} ; \mathrm{OCH}_{3}\right), 5.04\left(2 \mathrm{H}, \mathrm{s} ; \mathrm{CH}_{2}\right), 7.53(1$ $\mathrm{H}, \mathrm{d}, J=15.9 \mathrm{~Hz}$; vinyl proton $), 6.8-7.6(16 \mathrm{H}$, 
$\mathrm{m}$; aromatic protons $), 7.99(1 \mathrm{H}, \mathrm{d}, J=15.9 \mathrm{~Hz}$; vinyl proton).

1-(4-Benzyloxy-3-methoxyphenyl)-3-(2-benzyloxy-3-methoxyphenyl)-2,3-epoxy-1-propanone

(2). Chalcone 1 ( $9.6 \mathrm{~g}, 20 \mathrm{mmol})$ was dissolved in $50 \mathrm{ml}$ dichloromethane. A mixture of $10 \mathrm{ml} 35 \%$ hydrogen peroxide and $30 \mathrm{ml} 3 \mathrm{M}$ aqueous $\mathrm{NaOH}$ was added with cooling (ice bath) to below $4{ }^{\circ} \mathrm{C}$. With vigorous stirring, $1.4 \mathrm{~g}$ of solid tetrabutylammonium hydrogen sulfate were added in small portions during $10 \mathrm{~min}$. The mixture was stirred for $1 \mathrm{~h}$ at $4^{\circ} \mathrm{C}$ and for $2 \mathrm{~h}$ at room temperature. The organic layer was separated and washed twice with $1 \%$ aqueous ammonium sulfate, dried $\left(\mathrm{Na}_{2} \mathrm{SO}_{4}\right)$ and the solvent evaporated. Yellow oil $8.8 \mathrm{~g}(89 \%) .{ }^{1} \mathrm{H}$ NMR spectrum: $\delta 3.90\left(3 \mathrm{H}, \mathrm{s}\right.$; $\left.\mathrm{OCH}_{3}\right), 3.92(3 \mathrm{H}, \mathrm{s}$; $\left.\mathrm{OCH}_{3}\right), 4.10(1 \mathrm{H}, \mathrm{d}, J=1.9 \mathrm{~Hz} ;-\mathrm{CH}<), 4.22(1$ $\mathrm{H}, \mathrm{d}, J=1.9 \mathrm{~Hz} ;-\mathrm{CH}<), 5.00(2 \mathrm{H}, \mathrm{AB}$ spectrum, $\left.J=11.0 \mathrm{~Hz} ; \mathrm{CH}_{2}\right), 5.20(2 \mathrm{H}, \mathrm{s}$; $\left.\mathrm{CH}_{2}\right), \simeq 7(16 \mathrm{H}, \mathrm{m}$; aromatic protons).

1-(4-Benzyloxy-3-methoxyphenyl)-2-(2-benzyloxy-3-methoxyphenyl)-1,3-propanediol (3). To 2 $(4.7 \mathrm{~g}, 9.5 \mathrm{mmol})$, dissolved in $300 \mathrm{ml}$ dry diethyl ether was added $13.4 \mathrm{~g}$ freshly distilled $\mathrm{BF}_{3}$ diethyl etherate $(95 \mathrm{mmol})$. The mixture was refluxed for $30 \mathrm{~min}$ and the reaction was then stopped by the careful addition of water $(200 \mathrm{ml})$, dried $\left(\mathrm{Na}_{2} \mathrm{SO}_{4}\right)$ and evaporated to a small volume. The syrupy residue was dissolved in dioxane $(75 \mathrm{ml})$ and a solution of $1 \mathrm{~g}$ sodium borohydride in $25 \mathrm{ml} 0.1 \mathrm{M}$ sodium hydroxide was added dropwise (vigorous reaction). After 48 $\mathrm{h}$ at room temperature the mixture was acidified $(0.1 \mathrm{M} \mathrm{HCl})$ and extracted with ether $(200 \mathrm{ml}$ in three portions). The ether layer was washed with saturated sodium hydrogen carbonate solution and with water. After drying $\left(\mathrm{Na}_{2} \mathrm{SO}_{4}\right)$, evaporation of the solvent left an oil $(5 \mathrm{~g})$ which was chromatographed on a silica gel column $(120 \mathrm{~g}$, $\mathrm{CH}_{2} \mathrm{Cl}_{2}:$ EtAc $4: 1,10 \mathrm{ml}$ fractions). Fractions $19-31$ yielded a colourless oil $(1.8 \mathrm{~g}, 38 \%)$ which crystallized slowly on standing. Recrystallization from diethyl ether gave small white needles m.p. $97-100^{\circ} \mathrm{C}$. ${ }^{1} \mathrm{H}$ NMR spectrum of the acetate derivative: $\delta 1.88\left(3 \mathrm{H}, \mathrm{s} ; \mathrm{CH}_{3} \mathrm{CO}\right)$, $1.89\left(3 \mathrm{H}, \mathrm{s} ; \mathrm{CH}_{3} \mathrm{CO}\right), 3.70\left(3 \mathrm{H}, \mathrm{s} ; \mathrm{OCH}_{3}\right), 3.86$ $\left(3 \mathrm{H}, \mathrm{s} ; \mathrm{OCH}_{3}\right), 3.91(1 \mathrm{H}$, dd, $J=6.3$ and 10.7 $\left.\mathrm{Hz} ; \mathrm{H}_{\gamma}\right), 4.05\left(1 \mathrm{H}, \mathrm{m} ; \mathrm{H}_{\beta}\right), 4.20(1 \mathrm{H}, \mathrm{dd}, J=6.0$ and $\left.10.7 \mathrm{~Hz} ; \mathrm{H}_{\gamma}\right), 4.62(1 \mathrm{H}, \mathrm{d}, J=11.0 \mathrm{~Hz}$; methylene proton), $4.94(1 \mathrm{H}, \mathrm{d}, J=11.0 \mathrm{~Hz}$; methylene proton $), 5.09\left(2 \mathrm{H}, \mathrm{s} ; \mathrm{CH}_{2}\right), 6.05(1 \mathrm{H}$, $\left.\mathrm{d}, J=8.1 \mathrm{~Hz} ; \mathrm{H}_{\alpha}\right), 6.6-7.5(16 \mathrm{H}, \mathrm{m}$; aromatic protons).

1-(4-Hydroxy-3-methoxyphenyl)-2-(2-hydroxy3-methoxyphenyl)-1,3-propanediol (4). The dibenzyl ether $3(0.31 \mathrm{~g})$ was subjected to catalytic hydrogenation in dioxane $(15 \mathrm{ml})$ with $0.1 \mathrm{~g} 10 \% \mathrm{Pd} / \mathrm{C}$ as catalyst. After $1 \mathrm{~h}$ the hydrogen consumption ceased; the hydrogen uptake was $28 \mathrm{ml}$ ( $2 \mathrm{~mol}$ per mol of 3$)$. The catalyst was filtered off and the solvent evaporated. The product was an oil. ${ }^{1} \mathrm{H}$ NMR of the acetate derivative: $\delta 1.89\left(3 \mathrm{H}, \mathrm{s} ; \mathrm{CH}_{3} \mathrm{CO}\right), 1.93$ (3 H, s; $\left.\mathrm{CH}_{3} \mathrm{CO}\right), 2.27\left(3 \mathrm{H}, \mathrm{s} ; \mathrm{CH}_{3} \mathrm{CO}\right), 2.32$ (3 $\left.\mathrm{H}, \mathrm{s} ; \mathrm{CH}_{3} \mathrm{CO}\right), 3.71\left(3 \mathrm{H}, \mathrm{s} ; \mathrm{OCH}_{3}\right), 3.79(3 \mathrm{H}, \mathrm{s}$; $\left.\mathrm{OCH}_{3}\right), 3.81\left(1 \mathrm{H}, \mathrm{m} ; \mathrm{H}_{\beta}\right), 4.07(1 \mathrm{H}, \mathrm{dd}, J=7.1$ and $\left.11.2 \mathrm{~Hz} ; \mathrm{H}_{\gamma}\right), 4.34(1 \mathrm{H}$, dd, $J=6.3$ and 11.2 $\left.\mathrm{Hz} ; \mathrm{H}_{\gamma}\right), 6.06\left(1 \mathrm{H}, \mathrm{d}, J=7.6 \mathrm{~Hz} ; \mathrm{H}_{\alpha}\right), 6.7-7.2(6$ $\mathbf{H}, \mathbf{m}$; aromatic protons).

3-Hydroxymethyl-2-(4-hydroxy-3-methoxyphenyl)-7-methoxy-2,3-dihydrobenzo[b]furan (5). Dibenzyl ether $3(0.74 \mathrm{~g})$ was hydrogenated in $30 \mathrm{ml}$ methanol with $0.2 \mathrm{~g} 10 \%$ Pd on charcoal as catalyst. The hydrogen consumption ceased after $30 \mathrm{~min}\left(69 \mathrm{ml} \mathrm{H}_{2}\right)$ and the reaction was interrupted after $45 \mathrm{~min}$. The catalyst was filtered off and the solvent removed by film evaporation. The product was chromatographed $\left(60 \mathrm{~g} \mathrm{SiO}_{2}\right.$; eluent, dichloromethane: ethyl acetate 4:1). The purified product $(0.36 \mathrm{~g})$ crystallized on standing (m.p. ca $90^{\circ} \mathrm{C}$ ). Recrystallization from ethyl acetate-hexane gave crystals m.p. $93-95^{\circ} \mathrm{C}$. Mass spectral molecular weight: 302.1153 , calculated for $\mathrm{C}_{17} \mathrm{H}_{18} \mathrm{O}_{5}: 302.1154$. ${ }^{1} \mathrm{H}$ NMR spectrum of the acetate derivative: $\delta 2.04\left(3 \mathrm{H}, \mathrm{s} ; \mathrm{CH}_{3} \mathrm{CO}\right)$, 2.29 (3 H, s; $\left.\mathrm{CH}_{3} \mathrm{CO}\right), 3.79\left(1 \mathrm{H}, \mathrm{m} ; \mathrm{H}_{\beta}\right), 3.81(3$ $\left.\mathrm{H}, \mathrm{s} ; \mathrm{OCH}_{3}\right), 3.90\left(3 \mathrm{H}, \mathrm{s} ; \mathrm{OCH}_{3}\right), 4.32(1 \mathrm{H}$, dd, $J=7.6$ and $\left.11.1 \mathrm{~Hz} ; \mathrm{H}_{\gamma}\right), 4.45(1 \mathrm{H}$, dd, $J=5.5$ and $\left.11.1 \mathrm{~Hz} ; \mathrm{H}_{\gamma}\right), 5.52\left(1 \mathrm{H}, \mathrm{d}, J=6.8 \mathrm{~Hz} ; \mathrm{H}_{\alpha}\right)$, 6.8-7.2 (6 H, m; aromatic protons).

Acknowledgement. We wish to thank Professor E. Adler for valuable discussions and Göteborgs Kungliga Vetenskaps- och Vitterhetssamhälle for financial support to one of us (G.B.).

1. Adler, E. Wood Sci. Technol. 11 (1977) 169.

2. Erdtman, H. Justus Liebigs Ann. Chem. 503 (1933) 283.

3. Freudenberg, K. and Hübner, H. Chem. Ber. 85 (1952) 1181.

4. Nakatsubo, F. and Higuchi, T. Mokuzai Gakkaishi 25 (1979) 735.

5. Kristersson, P. and Lundquist, K. Acta Chem. Scand. B 34 (1980) 213.

6. Ahvonen, T., Brunow, G., Kristersson, P. and Lundquist, K. Acta Chem. Scand. B 37 (1983) 845 .

7. Aulin-Erdtman, G., Tomita, Y. and Forsén, S. Acta Chem. Scand. 17 (1963) 535.

8. Adler, E. and Lundquist, K. Acta Chem. Scand. 17 (1963) 13.

9. Ichihara, A., Kanai, S., Nakamura, Y. and Sakamura, S. Tetrahedron Lett. (1978) 3035.

Received December 30, 1983.

Acta Chem. Scand. B 38 (1984) No. 4 